\title{
Paleogeographic evolution and avulsion history of the Holocene Rhine-Meuse delta, The Netherlands
}

\section{H.J.A. Berendsen $\star \&$ E. Stouthamer}

The Netherlands Centre for Geo-Ecological Research (ICG)

Department of Physical Geography, Faculty of Geographical Sciences Utrecht University, PO Box 80.115, 3508 TC Utrecht, The Netherlands; e-mail: H.Berendsen@geog.uu.nl

* Corresponding author.

Received: January 2001; accepted November 2001

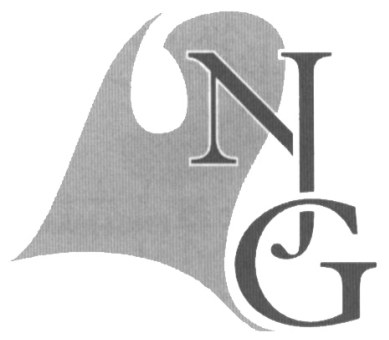

\begin{abstract}
Approximately 200,000 lithological borehole descriptions, $1200{ }^{14} \mathrm{C}$ dates, 36,000 dated archaeological artifacts, and gradients of palaeochannels were used to reconstruct the Holocene evolution of the fluvial part of the Rhine-Meuse delta. Ages of all Holocene channel belts were stored in a Geographical Information System database that enables generation of palaeogeographic maps for any time during the Holocene. The time resolution of the palaeogeographic reconstruction is about 200 years.

During the Holocene, avulsion was an important process, resulting in frequent shifts of areas of clastic sedimentation. Palaeogeographic evolution and avulsion history of the Rhine-Meuse delta are governed by complex interactions among several factors. These are: (1) Location and shape of the Late Weichselian palaeovalley. In the Early Holocene, rivers were confined to the Late Weichselian valley. When aggradation shifted upstream, the margins of the valley were crossed by newly formed channel belts. (2) Sealevel rise, which resulted in back-filling of the palaeovalley. (3) River channel pattern. In the central-western part of the delta, a straight anastomosed channel pattern with large-scale crevassing developed as a result of sealevel rise and the associated decrease of stream power. (4) Neotectonics. Differential tectonic movements of the Peel Horst and Roer Valley Graben seem to have influenced river behaviour (formation of an asymmetrical meander belt, location of avulsion nodes in fault zones), especially from $4500-2800{ }^{14} \mathrm{C}$ yr BP when the rate of sealevel rise had decreased. After $2800{ }^{14} \mathrm{C}$ yr BP sealevel rise further decreased, and tectonic influence still may have influenced avulsions, but from then on other factors became dominant. (5) Increased discharge, sediment load and/or within-channel sedimentation. After $2800{ }^{14} \mathrm{C}$ yr BP, meander wavelenghts increased, which is interpreted as a result of increased bankfull discharge and/or within channel sedimentation. After $2000{ }^{14} \mathrm{C}$ yr BP both discharge and sediment load increased as a result of human influence. (6) Coastal configuration. The limited number of tidal inlets and extensive peat formation restricted the number of avulsions in the western part of the delta, and enhanced channel reoccupation. (7) Composition of the substrate and river banks. Meandering river channels tended to adhere to the sandy margins of the Late Weichselian palaeovalley, and high channel sinuosity is found in areas where river banks consisted of sand. Peat formation, which was most extensive in the western part of the back-barrier area especially between 4000 and $3000{ }^{14} \mathrm{C}$ yr BP, more or less fixed the river pattern at that time, hampering avulsions. (8) Marine ingressions, e.g. the $1421 \mathrm{AD}$ St. Elizabeth's flood caused large-scale erosion in the southwestern part of the fluvial deltaic plain, resulting in a shift of the main drainage to the SW. (9) Human influence. Since about 1100 AD human influence dominated the palaeogeographic evolution. Rivers were embanked and natural avulsions did no longer occur.
\end{abstract}

Keywords: avulsion, Holocene geology, palaeogeography, palaeohydrology, Rhine-Meuse delta

\section{Introduction}

The Rhine/Meuse deltaic plain (Fig. 1) is situated in the southeastern corner of the North Sea Basin. Vir- tually all of the Holocene delta was created either by river sedimentation in a back-barrier area or by peat formation. In the western part of the delta, tidal flat and lagoonal deposits are intercalated with fluvial de- 


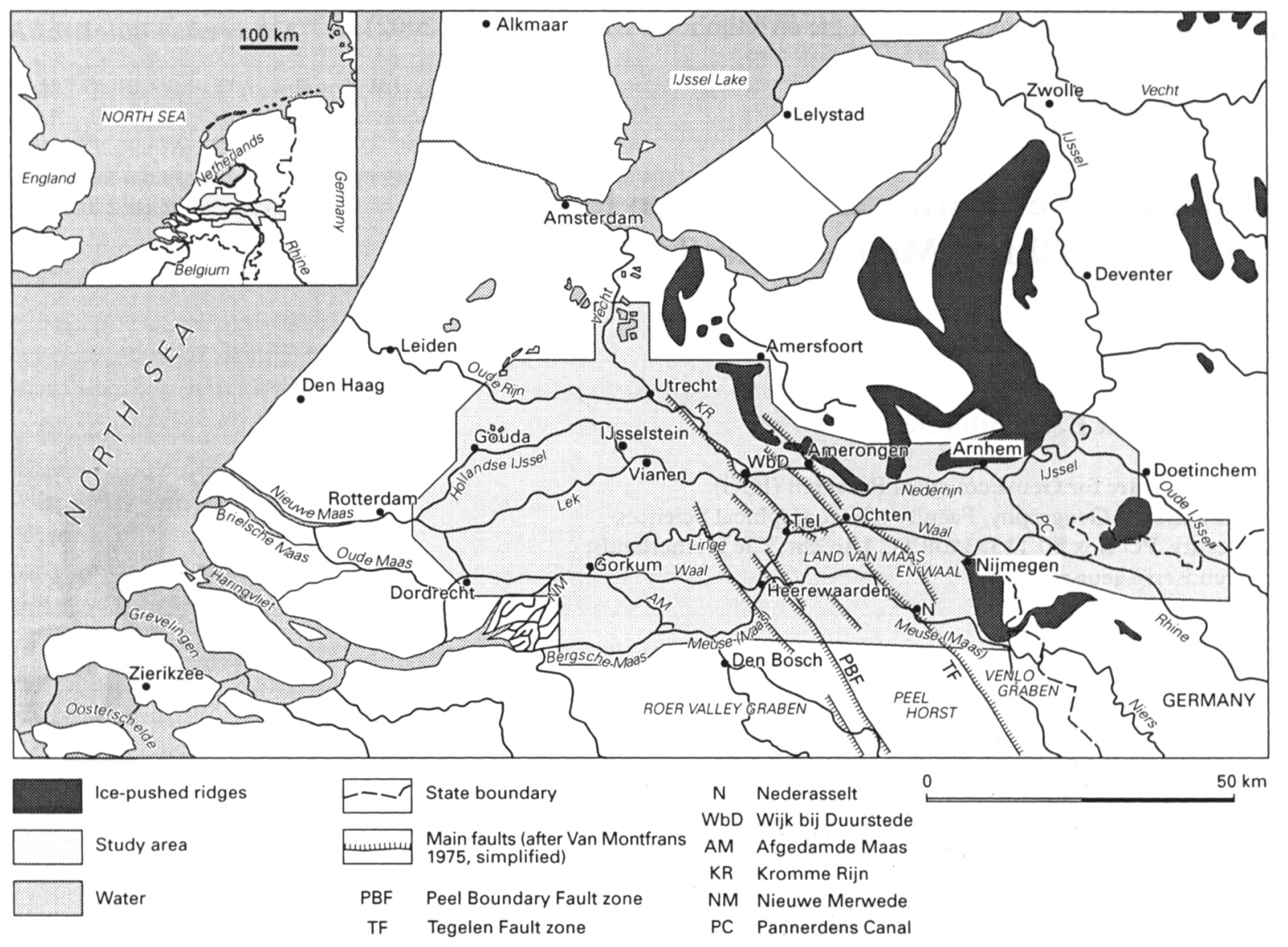

Fig. 1. The Holocene Rhine-Meuse delta in the Netherlands. The study area is the fluvial part of the delta. Main tectonic elements are the Peel Horst and the RoerValley Graben. The present main channels in the delta are the Nederrijn-Lek, Waal, IJssel (all three are Rhine distributaries) and Meuse (=Maas). The former Rhine distributaries Kromme Rijn-Oude Rijn, Hollandse IJssel and Linge were dammed berween approximately 1100 and $1300 \mathrm{AD}$.

posits. The thickness of the Holocene clayey floodbasin deposits varies from about $2 \mathrm{~m}$ near the border of Germany to about $20 \mathrm{~m}$ near the Dutch coast, where much of the Holocene sequence consists of peat. The Holocene fluvial plain and estuaries cover an area of about $5700 \mathrm{~km}^{2}$. Outside the Holocene alluvial plain, estuarine and tidal flat deposits prevail. The present mean annual discharge of the Rhine is about $2200 \mathrm{~m}^{3} / \mathrm{s}$; that of the Meuse (=Maas) is smaller by about a factor of ten. Rhine discharge is divided among three distributaries (Fig. 1): Waal $(67 \%$ of total discharge), Nederrijn-Lek $(22 \%)$ and IJssel $(11 \%)$. The Meuse has been a tributary of the Rhine during most of its history.

The Rhine-Meuse delta has been studied extensively. This is no surprise, considering that the Rhine is Europe's main waterway, and part of the densely populated delta plain is now below sealevel. New large-scale infrastructural works are planned or under way, making water control, coastal protection and a thorough understanding of the composition of the substrate of paramount importance.

A large number of studies has been carried out in parts of the Rhine-Meuse delta, leading to detailed regional palaeogeographic reconstructions (for references see Berendsen and Stouthamer 2001). The most important source of information for this paper was fieldwork carried out since 1973 by students of physical geography at Utrecht University under the supervision of the first author. Over the years, a large amount of data regarding the Holocene evolution of the Rhine-Meuse delta has become available, including over 200,000 lithological borehole descriptions and more than $1200{ }^{14} \mathrm{C}$ dates. The first palaeogeographic overview of the entire delta, based on this dataset, was published by Berendsen and Stouthamer (2000). For this reconstruction, also 36,000 dated archaeological sites from the ARCHIS database (State Service for Archaeological Investigations = Rijksdienst voor Oudheidkundig Bodemonderzoek) were used. A detailed palaeogeographic reconstruction incorporating all ${ }^{14} \mathrm{C}$ dates was published by Berendsen and Stouthamer (2001), including a full-colour geological map of all the Holocene channel belts at a scale of 1:100.000, and detailed palaeogeographic maps for every 500 -year time interval. These palaeo- 
geographic maps can also be viewed on the Internet: http://www.geog.uu.nl/fg/palaeogeography.

A detailed reconstruction of the avulsion history was published by Stouthamer and Berendsen (2000). In this paper, we summarize some of the main aspects of the palaeogeographic evolution and the avulsion history.

\section{Methods}

Detailed geomorphological and geological maps were made (scale $1: 10,000$ ) of the fluvial part of the RhineMeuse delta, based on a coring density varying from $30 / \mathrm{km}^{2}$ to more than $200 / \mathrm{km}^{2}$. Coring depth varies from a minimum of $2 \mathrm{~m}$ to a maximum of approximately $15 \mathrm{~m}$. All sediment cores were described at 10 $\mathrm{cm}$ intervals with regard to texture, organic matter content, gravel content, color, oxydized iron and calcium carbonate content (using a $5 \% \mathrm{HCl}$ solution), occurrence of groundwater, shell content and other characteristics (Berendsen 1982).

Holocene channel belts in the Rhine-Meuse delta occur as an intricate maze of sandbodies enclosed in clayey and peaty matrices. Younger river systems have eroded older channel belts, leaving only erosional remnants of the latter. It is clear that avulsion (defined by Allen (1965) as the abandonment of a part or the whole of a channel by a stream in favor of a new course) played an important role in the formation of the Rhine-Meuse delta (Berendsen 1982; Törnqvist 1993a). In total, 206 erosional remnants of channel belts were named and described. Subsequently, all erosional remnants were dated. The period of activity of a channel is defined as the time interval of clastic sedimentation in the channel belt (formation of sandy channel belt deposits) and of adjacent overbank deposits (silty and clayey natural levee deposits, crevasse splay deposits and floodbasin deposits).

Relative datings were obtained from geomorphological mapping, measuring the depth of calcium carbonate-rich layers in channel belts, comparing soil formation, constructing gradients of surfaces connecting the tops of (sandy) channel deposits of various channel belts (GTS lines), and pollen analysis. 'Absolute' ages were obtained from archaeological artifacts, radiocarbon dating, dendrochronology and historical evidence (for detailed information, see Berendsen and Stouthamer 2000 and Berendsen and Stouthamer 2001).

For almost all channel belts, archaeological evidence and ${ }^{14} \mathrm{C}$ dating yielded accurate age determinations. In the case of ${ }^{14} \mathrm{C}$ dating it was assumed that no important hiatuses occur at lithological boundaries (see also Berendsen 1982; Van Dijk et al. 1991; Törnqvist and Van Dijk 1993).

Gradient lines of channel belts (GTS lines) were used to connect channel belts that are now isolated due to later erosion. Downstream and upstream connections between channel belts were established using the GTS line method (Berendsen and Stouthamer 2000 ) in addition to ${ }^{14} \mathrm{C}$-dating. Once ages were determined, the period of existence of all channel belts was graphically displayed in a range chart (Fig. 2), and all channel belts were mapped in a Geographical Information System (GIS) in Arcinfo format. From this it is possible to plot which channels were active at any given moment during the Holocene, and also how many channels were active at the same time. Palaeogeographic maps were produced from the GIS database for 500 yr time intervals. The accuracy of direct ${ }^{14} \mathrm{C}$-dates of channel belts is considered to be about \pm 100 years. All ages in this paper are uncalibrated ${ }^{14} \mathrm{C}$ ages, unless stated otherwise.

\section{Palaeogeography during the Late Weichselian (12,900-10,150 yr BP)}

\section{Pleniglacial braidplain}

During most of the Weichselian glacial $(\sim 120,000-$ $10,150 \mathrm{yr} \mathrm{BP})$, the Rhine flowed through two valleys that are visible in the morphology of the top of the Pleistocene subsurface (Zagwijn 1986), while the Meuse joined the Rhine in the vicinity of Nijmegen. The Rhine course through the present IJssel valley (Fig. 1) presumably ceased to exist during the Middle Weichselian (Van de Meene and Zagwijn 1978: 349).

During the Weichselian-Pleniglacial $(\sim 70,000-$ $12,900 \mathrm{yr}$ BP), rivers were apparently braided as is suggested by the pattern of residual channels found in the eastern part of the delta (Pons 1957, Berendsen $e t$ al. 1995: 155; Kasse et al. 1995). The braidplain, generally known as Lower terrace (Pons 1957), consists of gravelly sand, and is easily distinguished from the overlying clayey Holocene sediments. Lower terrace deposits were described by Verbraeck (1984) as Kreftenheye-5 deposits. Downstream of the hinge line (which approximately coincides with the DutchGerman border), the Pleniglacial braidplain can be traced westward to the coast and even into the North Sea. Its depth increases from $2 \mathrm{~m}$ below the surface near the German border to about $20 \mathrm{~m}$ near the coast. The Pleniglacial, or at least pre-Allerød-interstadial, age of the deposits is supported by at least 14 radiocarbon dates of residual (braided) channels filled with peat (Berendsen et al. 1995) that date from 


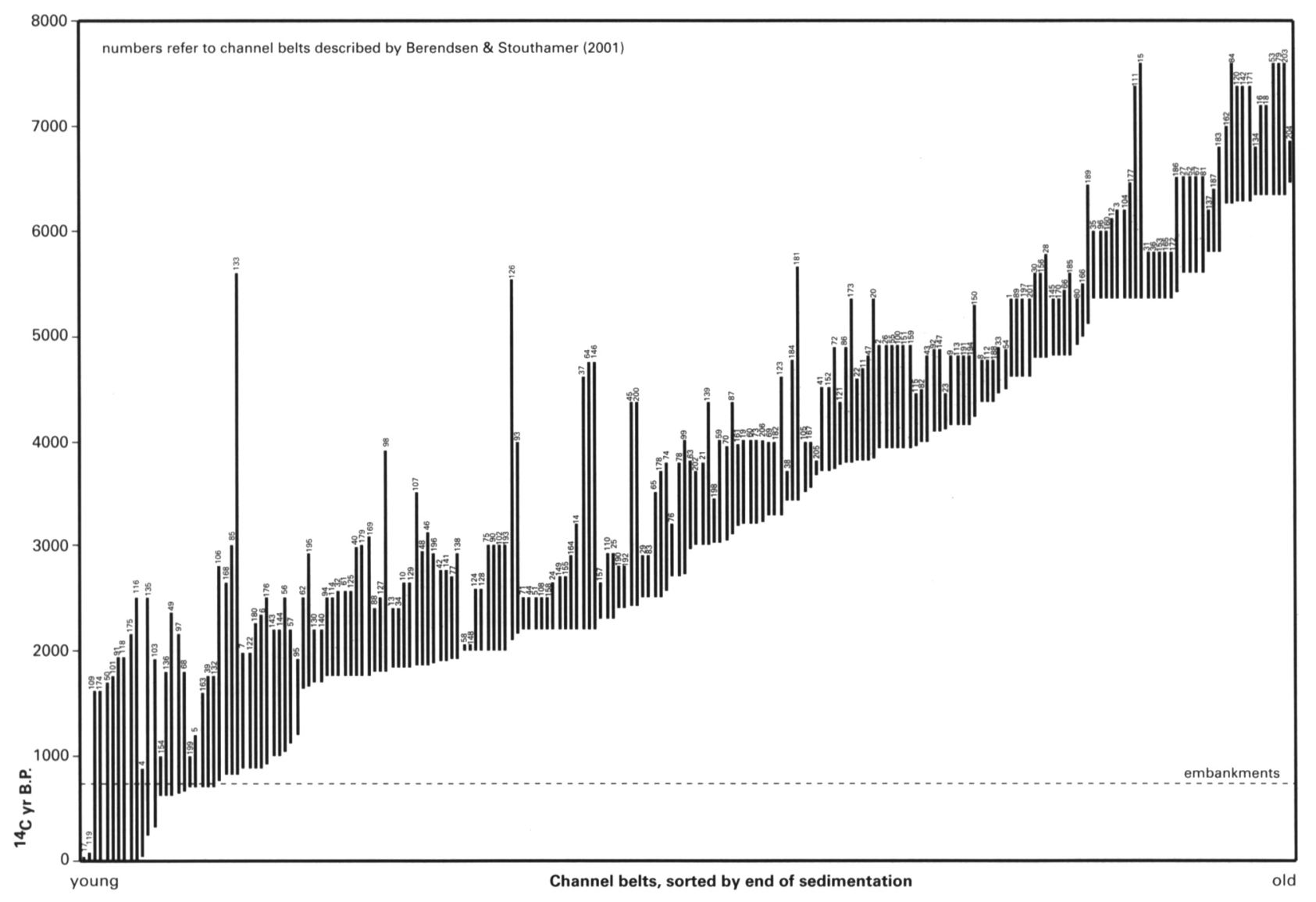

Fig. 2. Period of existence of channel belts in the Rhine-Meuse delta. The data are arranged according to ending activity of the channel belts. The average period of existence of channel belts is $\sim 1000 \pm 700{ }^{14} \mathrm{C}$ yr. Although variation is considerable, there is no significant trend over time.

the Bølling-Allerød-interstadial (12,900-10,950 yr BP; ages after Hoek 1997) or Younger Dryas (10,950$10,150 \mathrm{yr} \mathrm{BP})$. The occurrence of periglacial phenomena such as ice wedge casts and periglacial involutions in the sandy deposits further support its Pleniglacial age, as do two ${ }^{14} \mathrm{C}$ dates of intercalated peat layers that gave an age of $45,300 \pm 2000 \mathrm{yr} B P$ (GrN-5480) and 17,260 $\pm 105 \mathrm{yr} \mathrm{BP}(\mathrm{GrN}-6443)$ (Teunissen and Teunissen-Van Oorschot 1974).

\section{Bolling-Allerod interstadial Wijchen Member}

Rivers in the Rhine-Meuse delta changed to incised meandering streams during the relatively warm Bølling-Allerød interstadial (Pons 1957; Makaske and Nap 1995), and a 40-60 cm thick layer of tough, light grey or blueish to greenish clay, with a very low organic matter content (Pons and Schelling 1951, Pons 1957), was deposited on top of the Pleniglacial braidplain. The layer is believed to be formed by overbank sedimentation of incipient Bølling-Allerød interstadial and Early Holocene meandering rivers. Characteristics may vary locally, depending on the degree of weathering, soil formation and lithological properties
(Miedema 1987). The admixture of some fine and medium sized sand of eolian origin is a characteristic feature of this deposit. Sometimes isolated gravel is found, as well as iron concretions and loess nodules. This layer is presently known as the Wijchen Member (Törnqvist et al. 1994). The Wijchen Member occurs at the top of the Pleniglacial terrace all over the delta, is easy to distinguish because of the admixed eolian sand, and generally allows discrimination between the Holocene and Pleistocene deposits. Especially in the western part of the delta, where the Wijchen Member is covered by Holocene deposits, a characteristic vegetation horizon is present at the top of the Wijchen Member (Törnqvist et al. 1994). This type of horizon is presumably formed when groundwater levels are relatively high (Steenbeek 1990).

\section{Younger Dryas braidplain}

During the Younger Dryas stadial, rivers briefly reverted to a braiding pattern, and incised into the Pleniglacial braidplain, forming the so-called terrace X (Pons 1957, Berendsen et al. 1995, Kasse et al. 1995, Huisink 1997). Deposits consist of coarse sand 


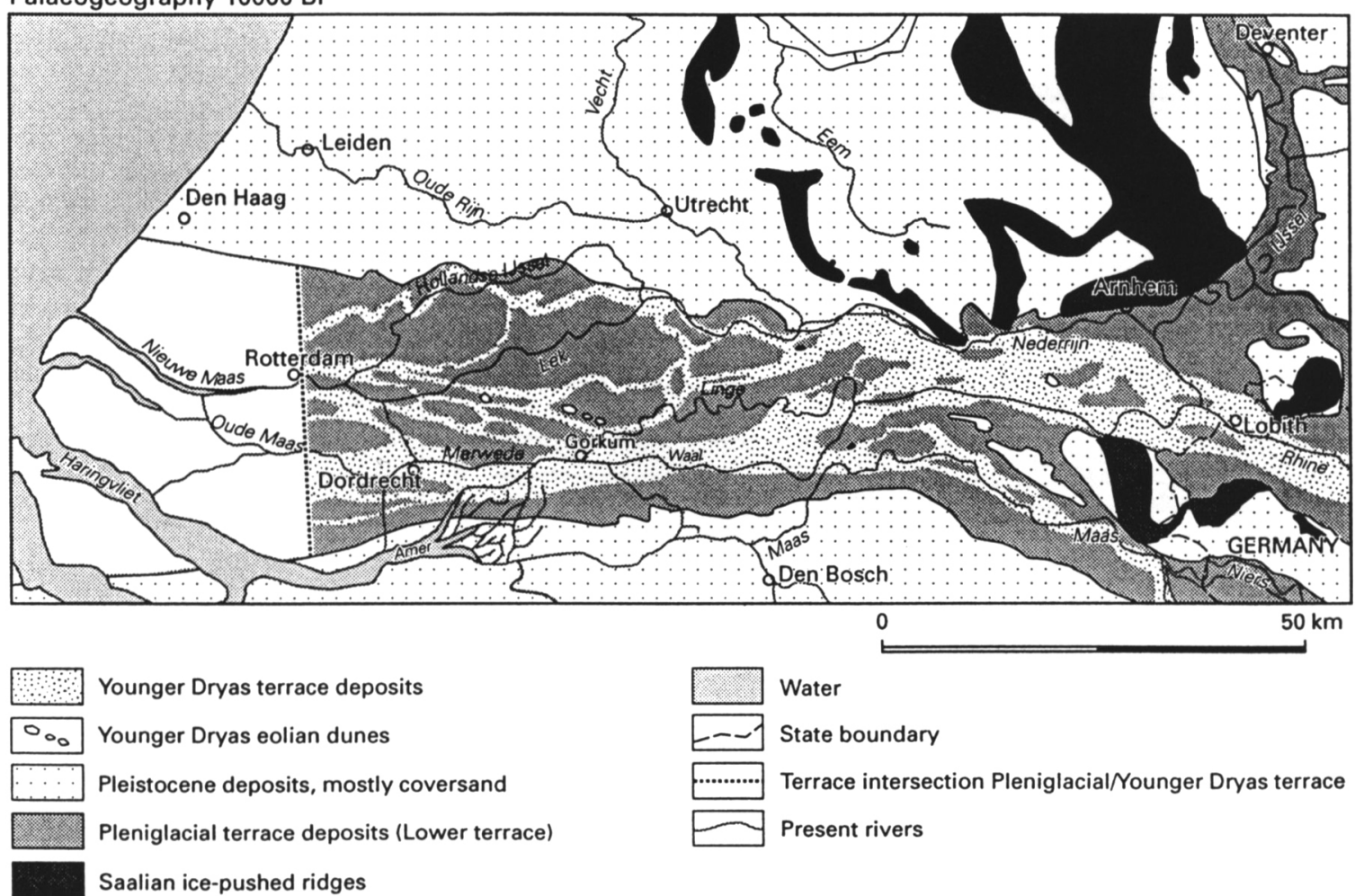

Fig. 3. Palaeogeography around 10,000 yr BP, showing Pleniglacial and Younger Dryas braidplains. The Pleniglacial braidplain in the western part of the delta is overlain by a thick Wijchen Member, in which two vegetation horizons developed. This allows to distinguish the Pleniglacial braidplain from the Younger Dryas braidplain (see text).

with gravel, and were described by Verbraeck (1984) as Kreftenheye- 6 deposits. As a result of this incision, the remnants of the Pleniglacial floodplain are recognized as a terrace in the area upstream of the hinge line. Downstream of the hinge line to Rotterdam, they are recognizable in the substrate as a buried terrace (Fig. 3). In the eastern part of the delta, the Younger Dryas deposits lie $2 \mathrm{~m}$ lower than the Pleniglacial terrace deposits (Berendsen et al. 1995). GTS lines of both levels slightly converge westward. The terrace intersection of these two levels occurred somewhere near Rotterdam (Törnqvist 1998).

At many locations, within the Younger Dryas deposits of the Rhine, pumice granules were found in a layer approximately $50 \mathrm{~cm}$ thick (Verbraeck 1984, 1990). The pumice, derived from the volcanic eruption of the Laacher See approximately $11,063 \pm 12 \mathrm{yr}$ BP (Friedrich et al. 1999), occurs in cross-stratified channel belt deposits. The pumice granules show little elevation scatter when plotted against longitudinal distance and closely parallel the gradient of the river. These observations suggest that the pumice was deposited in a braidplain and not in channels of meandering rivers. The pumice layer has been deformed by about $2 \mathrm{~m}$ as a result of differential tectonic movements of the Peel Horst (Fig. 4) and the Roer Valley Graben (Verbraeck 1990). Similar (but smaller) de- formations are found in gradient lines of Holocene channel belts (Fig. 4), as was shown by Stouthamer and Berendsen (2000). Tectonic movements also influenced Holocene river evolution, as shown below.

\section{Younger Dryas eolian dunes}

The second half of the Younger Dryas was a very dry period with strong eolian activity, as evidenced by extensive eolian dune formation along the braidplain (Vandenberghe 1987: 735; Berendsen et al. 1995). These dunes are still visible in the present-day landscape, and because of their relatively high elevation, they became the sites of early settlements. Pons (1957: 24) already noted that most dunes were deposited by southwestern winds, and occur northeastward of the Younger Dryas river valleys. However, detailed mapping shows that small dunes occur also to the south of these valleys, indicating occasional strong northern winds. Obviously, sand was blown out of the periodically dry braided river floodplain and deposited on the adjacent Pleniglacial terrace. The dunes generally overlie the Wijchen Member, as shown by at least 20 radiocarbon dates of humic clay or peat underlying the dune sand (Bohncke et al. 1993, Berendsen et al. 1995: 161) ${ }^{14} \mathrm{C}$ ages of the underlying peat vary from about $12,780 \mathrm{yr} \mathrm{BP}(\mathrm{GrN}-10161)$ to 


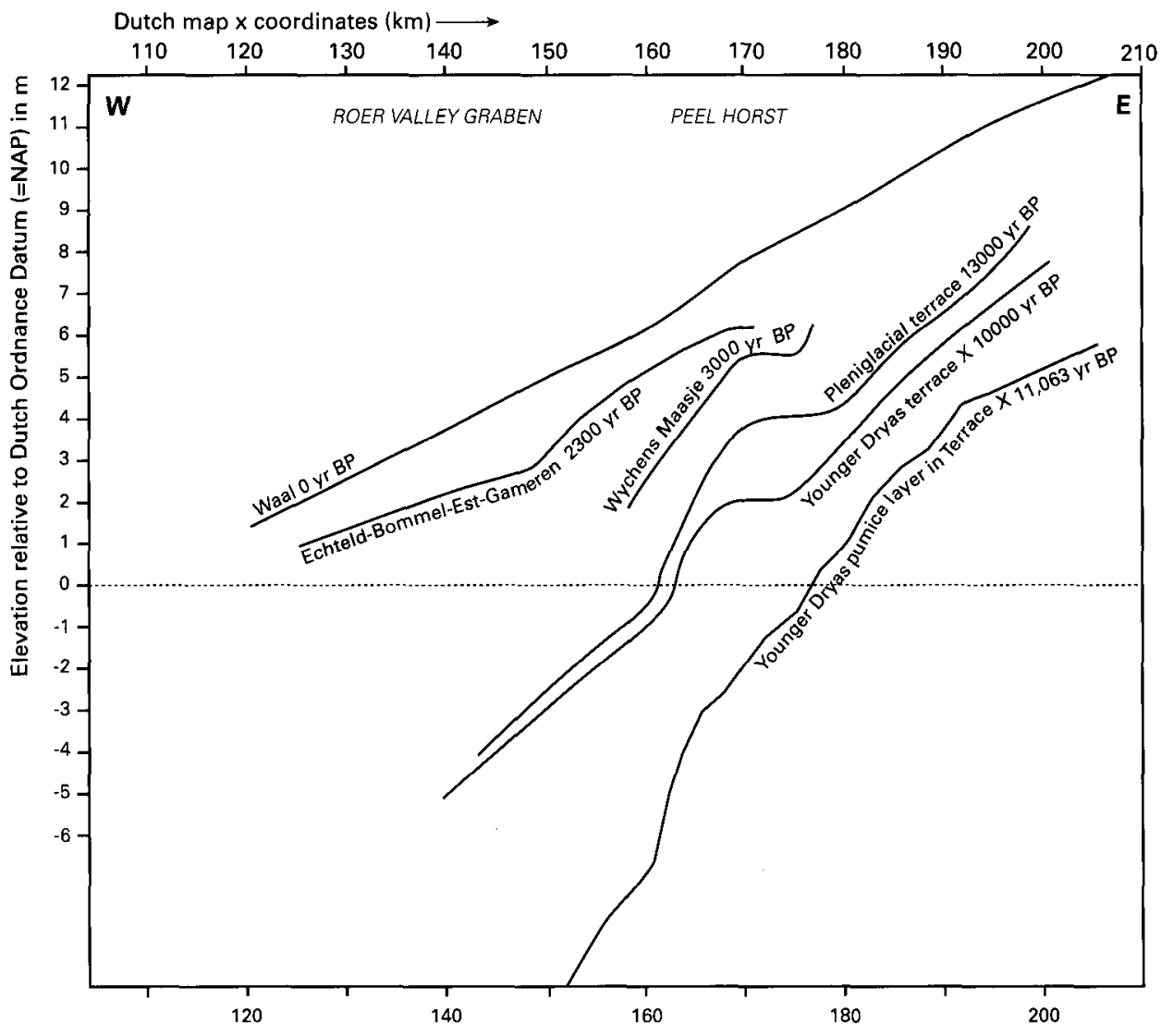

Fig. 4. Gradient lines of the Younger Dryas pumice layer (after Verbraeck 1990), the top of Late Weichselian terraces, and the top of Holocene channel belts crossing the Peel Horst, plotted along an E-W axis (after Stouthamer and Berendsen 2000). The influence of differential tectonic movements of the Peel Horst and Roer Valley Graben on gradient lines is evident.

10,240 yr BP (GrN-10931). Although it is generally agreed that dune formation stopped in the Early Holocene, the present parabolic shape of the dunes may partly be due to more recent eolian activity. Especially in the Land van Maas en Waal, floodbasin deposits tend to be enriched in wind-blown sand, and sometimes, thin intercalated sand layers are found in floodbasin clays flanking the dunes. This shows that limited eolian activity occurred also during the Holocene.

\section{Younger Dryas Wijchen Member}

On top of the sandy terrace $\mathrm{X}$ deposits (= Kreftenheye- 6 deposits) a circa $40 \mathrm{~cm}$ thick tough, blueish grey, clayey layer is found, similar to the Wijchen Member found on top of the Lower terrace. Lithological features are also similar, and it was not possible to lithologically distinguish the two layers, that are both described as Wijchen Member (Törnqvist et al. 1994). In this case, however, the layer was formed during the Early Holocene. At the top of this layer also a dark-grey or black vegetation horizon is present. Some ${ }^{14} \mathrm{C}$ dates of this vegetation horizon are available from the west-central river area, that show ages ranging from $8300 \pm 90 \mathrm{yr} \mathrm{BP}$ (GrN-18920) to 7440 \pm 160 yr BP (GrN-18938). Obviously this vegetation horizon was formed when the Wijchen Member was at the surface, just before large-scale aggradation started as a result of onlap caused by relative sealevel rise.

In the western part of the delta, the Pleniglacial, and Younger Dryas braidplains cannot be easily distinguished on the basis of their elevation, because variability within the 'terrace levels' is greater than elevation differences between the terraces. Near Rotterdam, however, the Wijchen Member occurs in two layers with a vegetation horizon at the top of each layer (Fig. 5). The lower layer is presumably of Allerødinterstadial (or Younger Dryas) age, whereas the upper layer is of Early Holocene age. The two layers can only be found in a single core at locations, where the Pleniglacial terrace occurs (Fig. 5), because the Wijchen Member of Allerød-interstadial age has been eroded at localities where the Younger Dryas terrace is present. The thickness of the upper Wijchen Member on top of the Lower terrace decreases eastward (Fig. 6), where the two vegetation horizons merge. Further to the east the upper layer occurs in the incised Younger Dryas valley. This means that the area where the two vegetation horizons are found on top of each other, must be located close to the terrace intersection of the Pleniglacial terrace and the Younger Dryas terrace. This information has been used to map the areal extent of the terraces in the western part of the delta (Fig. 3). The areal extent of the Younger Dryas 
Cross section a: eastern and central Netherlands
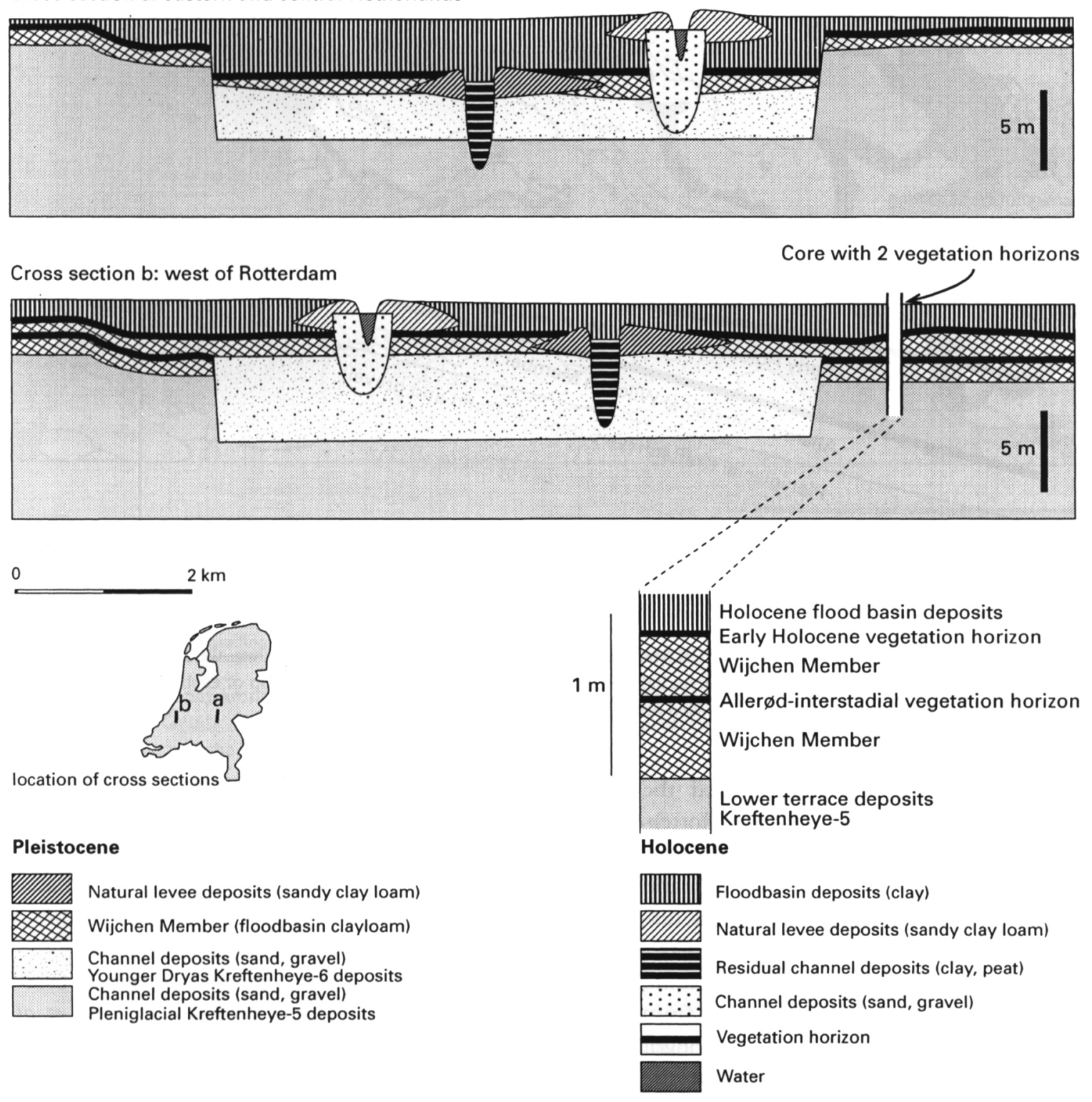

Fig. 5. Vegetation horizons in the Wijchen Member (schematic diagram representing the situation in the Early Holocene). Cores from the western Rhine-Meuse delta often contain two vegetation horizons: the lower one of Allerød-interstadial age, and the upper one of Early Holocene age. This means that the sandy deposits in the substrate must be part of the Pleniglacial Lower terrace.

terrace (Fig. 3) differs considerably from an earlier map published by Verbraeck (1990).

\section{Holocene (10,150 yr BP-present)}

The Holocene palaeogeographic evolution and avulsion history of the Rhine-Meuse delta is a result of a complicated interaction of various factors. Long-term factors such as sealevel rise, neotectonics, discharge variations and/or within-channel sedimentation, and human impact influenced avulsions over time scales of millennia. Over time, each of these factors played a dominant role in certain phases of the avulsion history. Below, examples are given of the influence of each of the factors, based on Berendsen and Stouthamer (2001). Substrate may locally have influenced the avulsion locations in all phases of the palaeogeographic evolution.

\section{Shape of LateWeichselian valleys}

When the ice sheets started melting approximately 18,000 years ago, sealevel started to rise, but due to the relatively high elevation of the southern North Sea Basin, this rise was felt only comparatively late (around $7500 \mathrm{yr}$ BP) near the present coastline. The morphology of the Pleistocene substrate influenced Holocene river and coastal evolution up to the pre- 


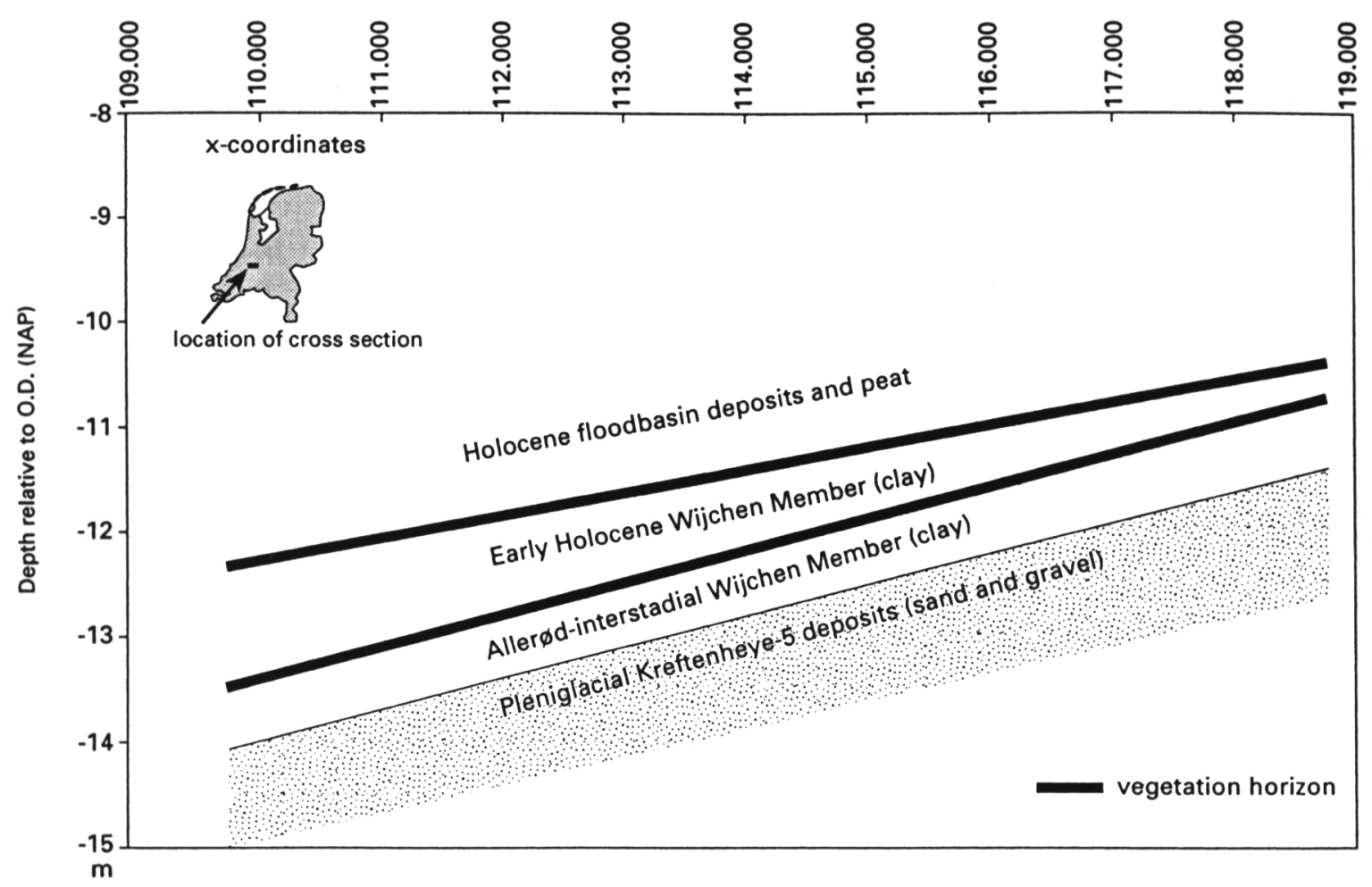

Fig. 6. Eastward converging vegetation horizons in the Wijchen Member. Near the terrace intersection of the Lower terrace and terrace X the vegetation horizons in the Wijchen Member of Allerød-interstadial age and of Early Holocene age occur on top of each other and converge eastward. The gradients of the two vegetation horizons are based on approximately 130 corings.

sent (Berendsen 1998). The sea first invaded the mouths of the Pleistocene river valleys near Rotterdam and Alkmaar (Fig. 1).

In the early Holocene, climatic warming and restoration of vegetation led to a decrease of peak discharges of the rivers, a decrease of bedload, and a relative increase in the load of fines (Berendsen et al. 1995). This resulted in a change of river pattern from aggrading braided channels to deeply incising straight or only slightly meandering channels. Throughout the delta, we found similar channels filled with peat or gyttja. The infilling of all of these channels was dated between $9800 \mathrm{yr}$ BP and $8000 \mathrm{yr}$ BP. The RhineMeuse system at that time was concentrated in a few large, incised, meandering channels, and the smaller channels draining the former Younger Dryas braidplain were in a state of degradation and peat formation. This suggests that discharge decreased dramatically in the beginning of the Holocene.

The oldest known aggrading Holocene river system is the Benschop river system (Berendsen 1982: 145) that existed from 7600 to $5350 \mathrm{yr}$ BP. The channel belts of this system (Fig. 7) occur at relatively great depth (>10 m) near Rotterdam. The Benschop river system was initially confined to the Younger Dryas valley, but as a result of continuing aggradation, the main channel avulsed near Gouda and crossed the northern margin of the valley at approximately 6500 yr BP (a smaller avulsion occurred near IJsselstein, Fig. 1). The main channel debouched into a wide tidal area between Den Haag and Leiden (Fig. 7).

\section{Sealevel rise}

From 7500 yr BP onwards, sealevel rise started to influence the gradients of the rivers (Van Dijk et al. 1991), causing fluvial aggradation in the area west of the terrace intersection, and enhancing avulsions. Further to the east, rivers were still incised, with the exception of a meander west of Nijmegen (Fig. 7) located in the Venlo Graben. Obviously aggradation in the Venlo Graben started earlier than on the upthrown Peel Horst. Since the influence of sealevel rise was felt earlier in the lower western part of the country, clayey floodbasin deposits on top of the sandy Pleistocene subsurface are younger towards the east. Similarly, avulsions could take place earlier in the western part of the deltaic plain than in the eastern part (Stouthamer and Berendsen 2000) because in the east, rivers were still incised. On the palaeogeographic maps (Figs. 7, 8 and 9), it can be seen that aggrading channel belts occur progressively further to the east with time. Also, the area where avulsions took place progressively shifted upstream.

Approximately $6500 \mathrm{yr} \mathrm{BP}$, the terrace intersection of Holocene deposits and the Pleniglacial terrace was 


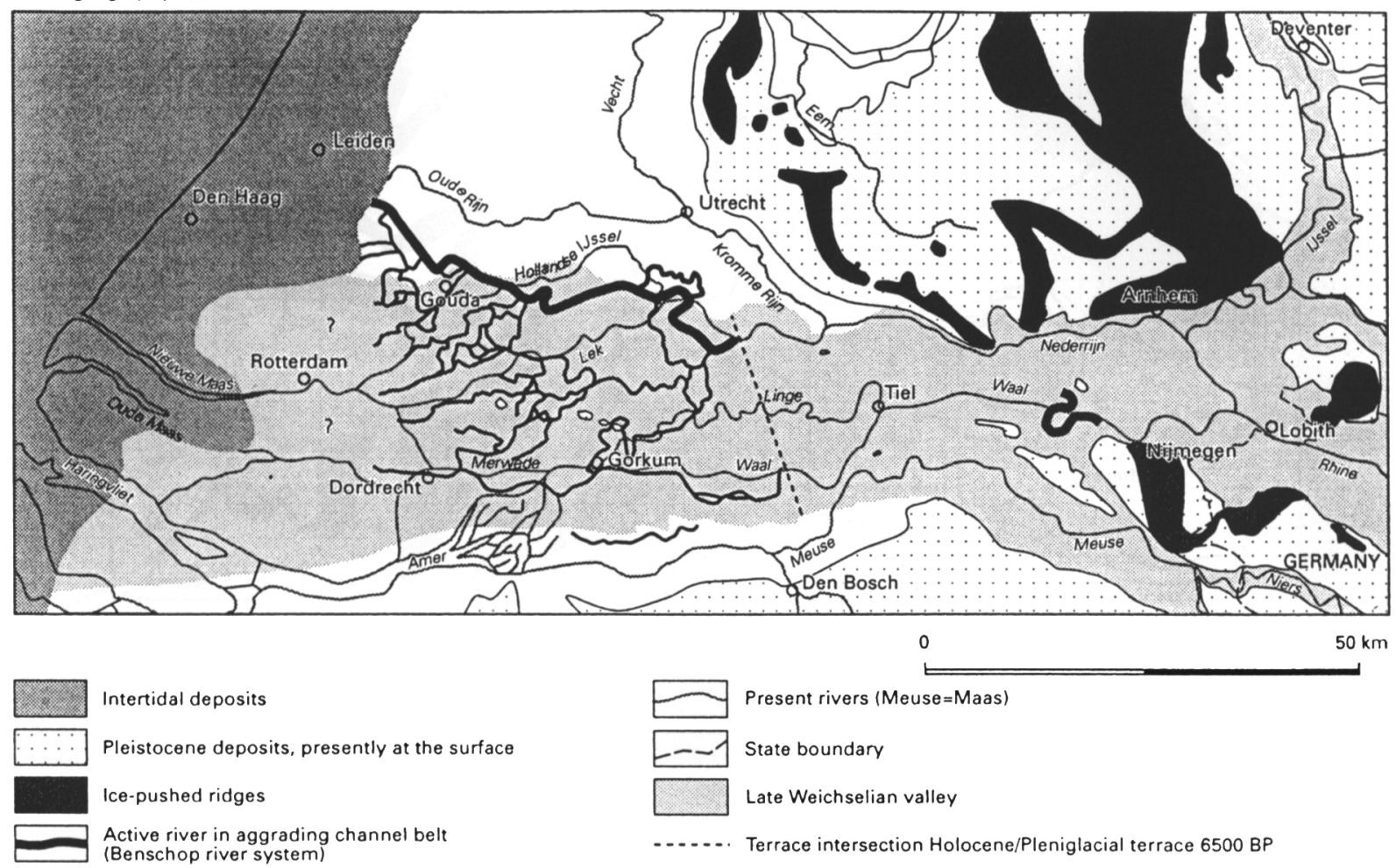

Fig. 7. Palaeogeography around 6500 yr BP: the Benschop river system. The main channel crossed the northern border of the Late Weichselian valley near Gouda. Back-filling of the Late Weichselian valley had progressed eastward to the dashed line (the terrace intersection of Holocene deposits and the Pleniglacial terrace).

located just west of the Peel Boundary Fault. The main channel of the Rhine flowed SE-NW, but there were many smaller channels flowing to the SW (Figs. 7 and 8 ).

\section{Neotectonic movements}

Approximately $5500 \mathrm{yr}$ BP, a major avulsion occurred near Wijk bij Duurstede (compare Fig. 7 and 8). The Benschop river system was abandoned in favour of the new Utrecht river system. This 'Oude Rijn' course remained the main Rhine course until $1122 \mathrm{AD}$, when the river was dammed at Wijk bij Duurstede, and discharge was diverted to the Lek. The avulsion site is located near Wijk bij Duurstede on the tectonically active Peel Boundary Fault zone that borders the Peel Horst to the west (Fig. 1).

After $4500 \mathrm{yr} \mathrm{BP}$, the rate of sealevel rise decreased, and the coastal barrier became closed, leading to extensive peat formation in the back-barrier area. The influence of sealevel rise on the rivers in the back-barrier area diminished considerably. During this time of relatively slow vertical accumulation, the river channels seem to have been influenced by tectonic movements of the Peel Horst and the Roer Valley Graben. There are numerous indications for tectonic influence in the river area. These include: (1) the development of an asymmetrical meander belt southeast of Amerongen (Fig. 1), as a result of tilting of the Peel Horst (Stouthamer and Berendsen 2000); (2) deformation of Late Weichselian terraces and GTS lines of Holocene channel belts and of the Late Weichselian pumice level (Fig. 4), see Stouthamer and Berendsen (2000); and (3) differences in the age of basal peats on both sides of the Peel Boundary Fault (Weerts and Berendsen 1995, Törnqvist et al. 1998). Although there is no evidence for avulsions being directly triggered by earthquakes, the location of numerous avulsion locations, and especially two nodal avulsion locations (sites where multiple avulsions occurred), near Wijk bij Duurstede and Tiel, in the tectonically active Peel Boundary Fault zone, suggests that tectonic movements may also have influenced avulsion. Two other nodal avulsion sites (Ochten and Nederasselt, Fig. 1) occur at the eastern boundary of the Peel Horst (Stouthamer and Berendsen 2000) in the Tegelen Fault zone (Figs. 8 and 10).

\section{Coastal configuration}

The morphology of the coast changed from an open coast around $5000 \mathrm{yr} \mathrm{BP}$ (Fig. 8) to a barrier island coast (Fig. 9) around 4500 yr BP (Zagwijn 1986, Beets et al. 1992). Approximately 5300 yr BP, the old- 


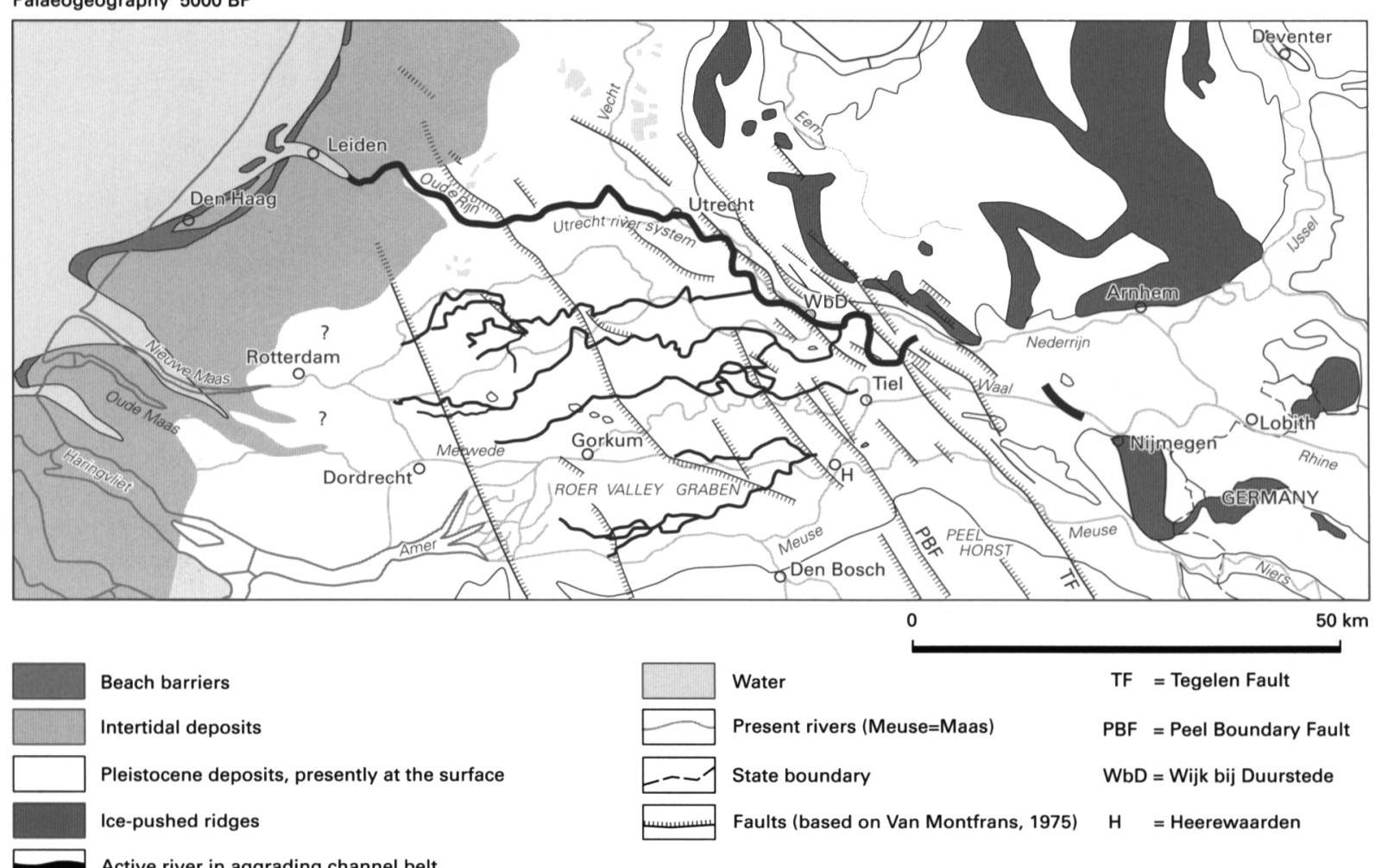

Fig. 8. Palaeogeography around 5000 yr BP: the Utrecht river system. Around 5500 BP a major avulsion occurred near Wijk bij Duurstede. The main Rhine distributary followed the direction of maximum tilt of the structural elements. The Oude Rijn channel remained active from about 5500 yr BP to $1122 \mathrm{AD}$.

Palaeogeography $4000 \mathrm{BP}$

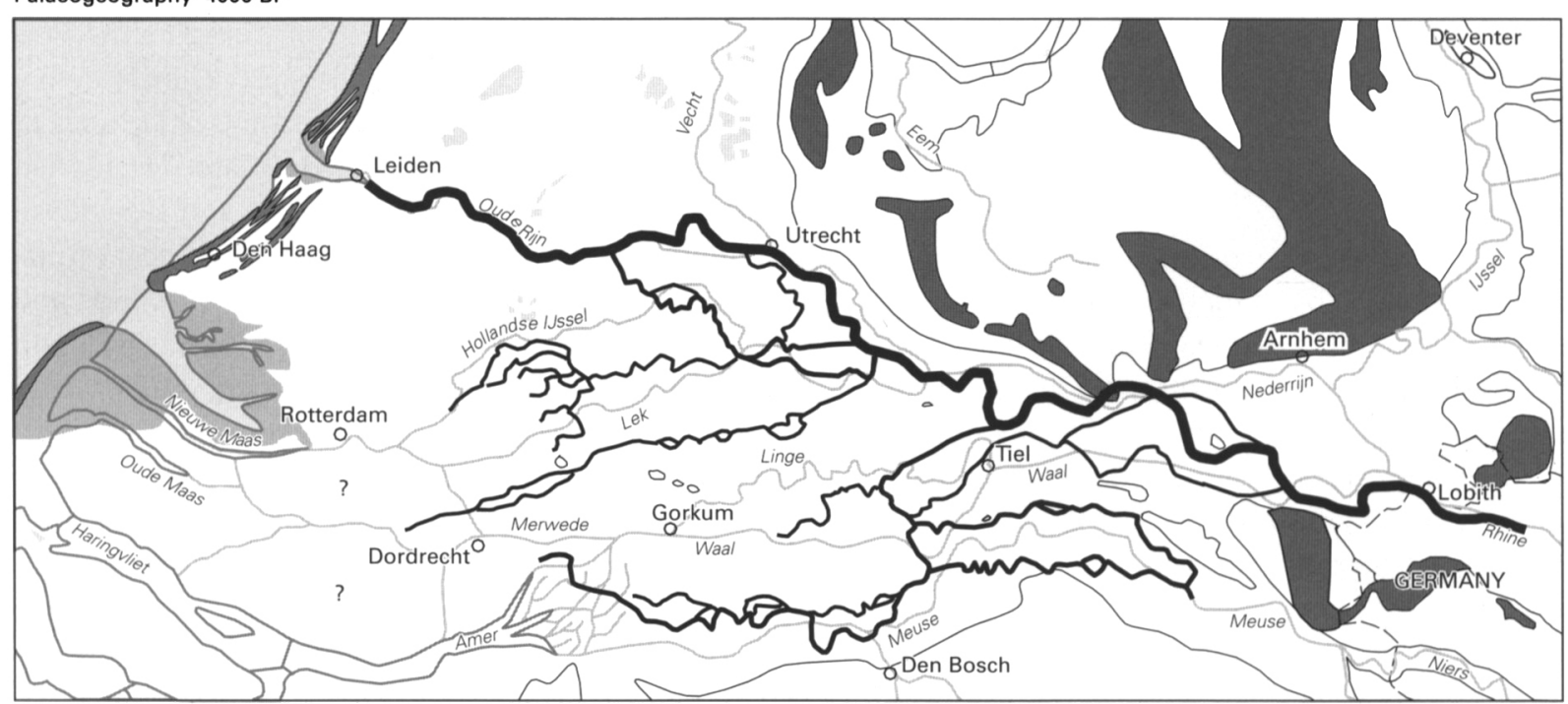

$50 \mathrm{~km}$

Beach barriers

Intertidal deposits

Pleistocene deposits, presently at the surface

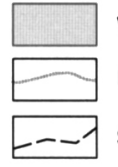

Water

Present rivers (Meuse=Maas)

Ice-pushed ridges

Active river in aggrading channel belt

Fig. 9. Palaeogeography around $4000 \mathrm{yr}$ BP: main discharge of the Rhine followed the Utrecht river system. There were some smaller channels branching off to the SW. The River Meuse (=Maas) closely followed the southern margin of the Late Weichselian valley. The exact location of river courses south of Rotterdam is unknown, partly because of later erosion. 


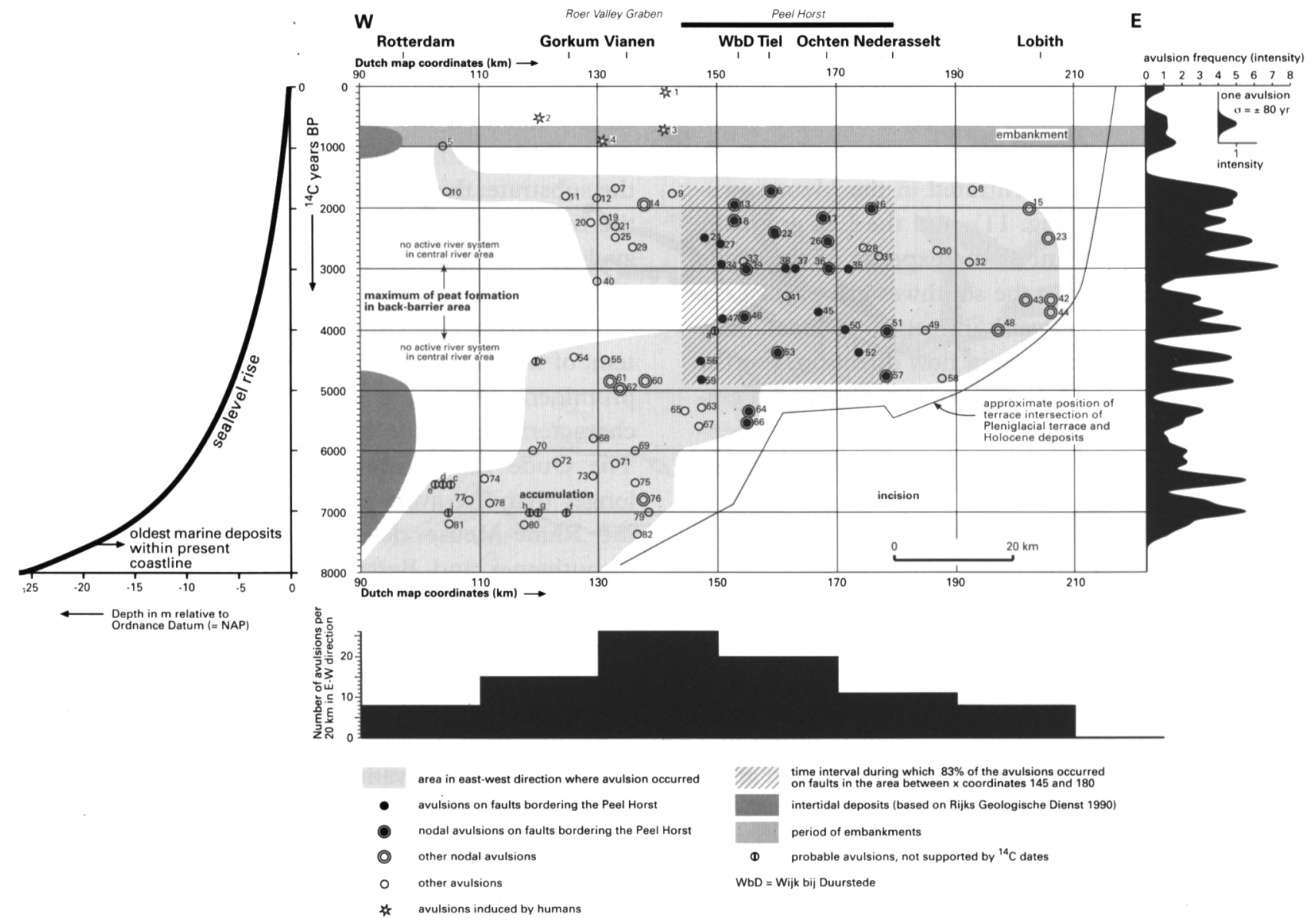

Fig. 10. Sealevel rise, location of the avulsion sites in the Rhine-Meuse delta, plotted on an E-W axis, and avulsion frequency during the Holocene. The spatial distribution of avulsions is related to: sealevel rise $(7500-3700 \mathrm{yr} \mathrm{BP})$, neotectonics $(4900-1700 \mathrm{yr} \mathrm{BP})$, increased discharge and/or within-channel sedimentation (2800-1000 yr BP), and human influence (after $1000 \mathrm{yr}$.BP). Note that the tectonic elements (Roer Valley Graben, Peel Horst and Venlo Graben) cut this section at an angle. Most avulsions occurred in the central.part of the delta and around the western fault zone of the Peel Horst (between coordinates 130 and 170). The avulsion frequency reached a maximum between 3000 and $1700 \mathrm{yr}$ BP; lowest avulsion frequencies occurred from 5300 to $5000 \mathrm{yr} \mathrm{BP}, 3500$ to $3000 \mathrm{yr} \mathrm{BP}$, and after $1500 \mathrm{yr}$ BP.

est barriers formed just east of the present coastline (Fig. 8). From that time on, considerable coastal progradation occurred in the central part of the coast (between Den Haag and Alkmaar, Fig. 1), due to a decreasing rate of sealevel rise. River sedimentation hardly seems to have influenced coastal progradation, since the barriers mainly consist of reworked Pleistocene sand (Van der Valk 1992) that was easily transported onshore by waves in the shallow North Sea.

Landward of the barriers, avulsion and crevassing played an important role in forming a complex matrix of peat with intercalated clay layers and channel belts with very low sandbody width/thickness ratios $(<15)$. Many small and narrow channel belts split off to the southwest from the main Rhine distributary (Figs. 7, 8,9 ), but none of these channels ever became the main Rhine channel, presumably because these channels could not attain a sufficient gradient advantage (the distance to the sea was longer than via the Oude Rijn). Although many crevasse splays were formed, the number of successful avulsions was low.
Approximately 2500 yr BP, the palaeogeographic situation had changed considerably, although the Kromme Rijn-Oude Rijn (Utrecht river system) still was the principal distributary of the Rhine. Especially in the area between Wijk bij Duurstede and Utrecht, new channel belts had formed that rejoined again further downstream. Only one of these channels (the Vecht, Fig. 11) found its way to the northwest, emptying into a series of lakes that later became the Zuiderzee (now IJssel Lake, Fig. 1), and eventually into the North Sea south of Alkmaar. West of Utrecht, the Oude Rijn remained the main Rhine channel. Southwest of Tiel (Fig. 11), however, important distributaries that followed a NE-SW course began to develop. They eventually may have joined the river Meuse west of Dordrecht and emptied into the Meuse estuary near Rotterdam. At this time there were virtually no fluvial channels in the central part of the delta, where peat formation was predominant.

Shortly after $2000 \mathrm{yr}$ BP, the present rivers Lek, Waal, Linge, Hollandse IJssel and Gelderse IJssel 
came into existence (Van de Meene 1979, Berendsen 1986, 1990). The Lek and Linge originated from the two most important nodal avulsion sites in the RhineMeuse delta, namely, near Wijk bij Duurstede (Lek) and Tiel (Linge). Remarkably, the discharge of the Rhine then became concentrated in the Meuse estuary near Rotterdam (Fig. 11), and the Lek gradually became more important at the expense of the Oude Rijn. Coastal erosion in the southwestern part of the delta, leading to landward influence of tides, may have stimulated this change in flow direction. For the first time the smaller NE-SW courses obtained a gradient advantage that was great enough to enable enlargement of the incipient channels, thereby attracting more water. This led to silting up of the older channels, especially those of the Utrecht river system.

\section{River channel pattern}

Between approximately 8000 and $4000 \mathrm{yr} \mathrm{BP}$, a remarkable river pattern developed in the central western part of the delta, roughly between Gorkum and Rotterdam (Figs. 7, 8, and 9). It consisted of an anastomosing complex of mostly low-sinuosity or straight channels, showing virtually no lateral accretion. Channels have low width/thickness ratios that decrease downstream to $<10$. This river pattern, that is characterized by large-scale crevassing, was formed under low stream power conditions (Makaske 1998), and relatively high accumulation rates (Törnqvist 1993b), caused by the fast rate of sealevel rise. The anastomosing system shifted upstream between 7000 yr BP and 2500 yr BP (compare Figs. 7, 8, and 9). However, it never crossed the Peel Horst. In the westcentral part of the delta, the straight anastomosing system ceased to exist around $4000 \mathrm{yr}$ BP (Törnqvist 1993a), when the rate of sealevel rise decreased.

In the southern part of the delta, the Meuse followed various courses to the west that were often connected to the Rhine by small distributaries (Fig. 9). Meuse channel belts older than $6000 \mathrm{yr}$ BP are relatively fragmentary due to later erosion. Individual Meuse channels were of the meandering type, although the large-scale pattern was also anastomosing (cf. Makaske 1998).

\section{Composition of substrate and river banks}

Sandy crevasse splays developed at locations where channel belts of different age intersect (Berendsen 1982). This occurs especially in the area where straight anastomosing channels were formed. Crevasse splays may be the first stage of an avulsion (Smith et al. 1989). Unlike the straight anastomosing channels, the meandering channels formed few, if any, sandy crevasse splays.

All Meuse distributaries younger than 6000 yr BP closely followed the margin of the Late Weichselian valley. This seems to be related to the composition of the substrate: the easily erodible sandy banks enabled the rivers to stay in this area instead of migrating or avulsing into the clayey and peaty central part of the delta.

The prolonged existence of the Utrecht river system, of which the Oude Rijn channel belt is the most prominent feature, is one of the most remarkable characteristics of the Holocene Rhine-Meuse delta. The Oude Rijn existed for $4600{ }^{14} \mathrm{C}$ years, much longer than the average life span of channel belts in the Rhine-Meuse delta, which is $1280{ }^{14} \mathrm{C}$ years (Stouthamer and Berendsen 2001). Although avulsions occurred in the upstream area, many of the avulsed channels rejoined the Oude Rijn further downstream and reoccupied the existing channel near Woerden.

Further west, cross-valley gradients were very low, and a gradient advantage in a different direction could not be achieved. Moreover, there were only two tidal inlets: near Leiden and near Rotterdam. Lateral migration was also very restricted, because in this area river banks consisted of compacted wood peat, which resists erosion (relative to sand). This forced the river to rework its own deposits continuously. Crevasse splays in the near-coastal area are numerous, but these never developed into avulsions.

\section{Increased discharge and/or within-channel sedimentation}

Detailed palaeogeographic maps published by Berendsen and Stouthamer (2001) show an increase in meander wavelengths of both Rhine and Meuse channels after approximately $2800 \mathrm{yr}$ BP. According to Allen 1965 meander wavelength ( $L$, in $\mathrm{m}$ ), is positively correlated to channel width ( $\mathrm{w}$, in $\mathrm{m}$ ) and bankfull discharge $\left(\mathrm{Q}\right.$, in $\left.\mathrm{m}^{3} / \mathrm{s}\right)$.

An increase in meander wavelength may therefore be a result of an increase in bankfull discharge, or an increase in channel width, or both. From our data it is presently hard to determine which of the two factors was dominant, and we can only speculate about the reason for the observed increase of the meander wavelength. In principle, an increase of discharge of one channel could have been coeval with a decrease of discharge in another channel. However, the Meuse only had one channel at this time (Fig. 11), and for the Rhine, the number of coeval channels increased. A study by Van Geel et al. (1996) suggests, that increased bankfull discharge after $2800 \mathrm{yr}$ BP may ini- 


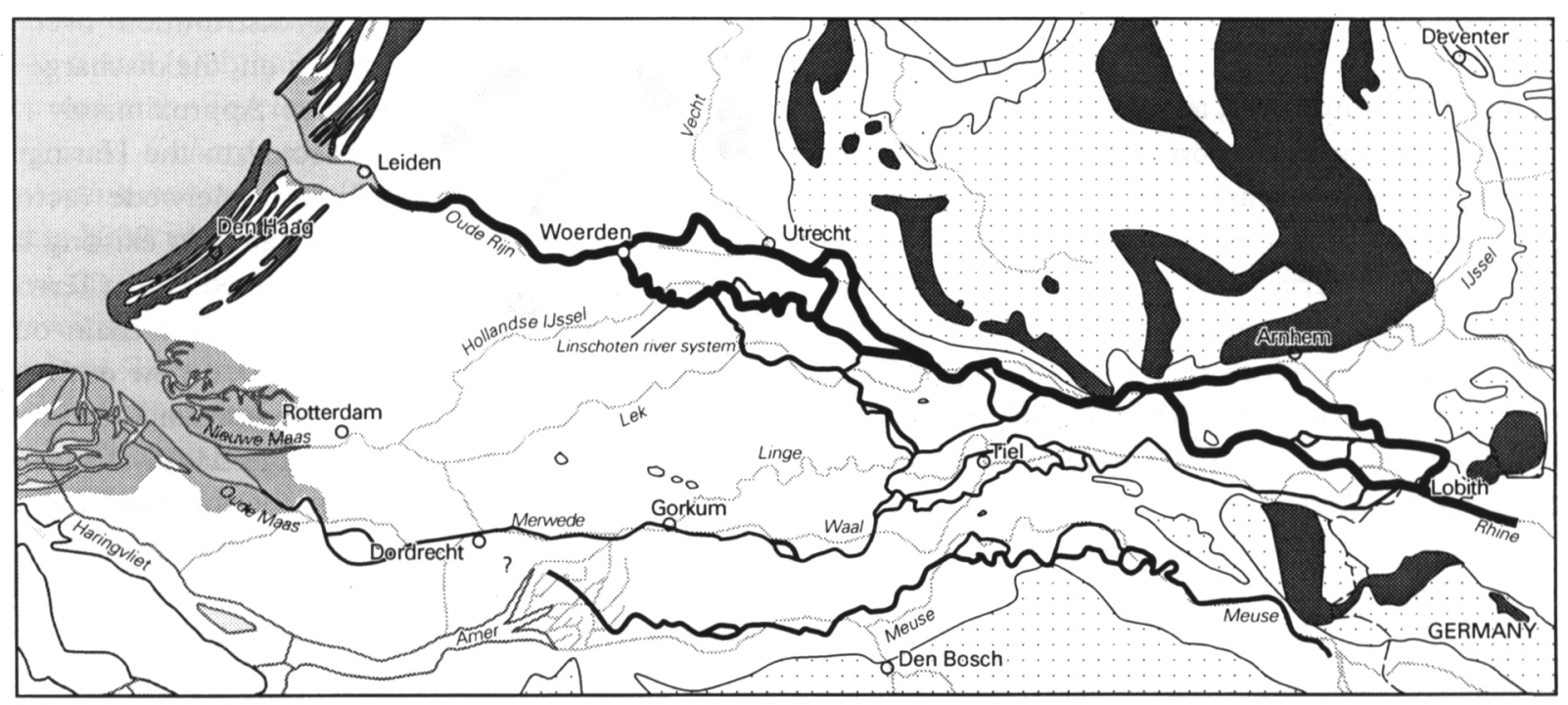

b) Palaeogeography 1250 yr BP

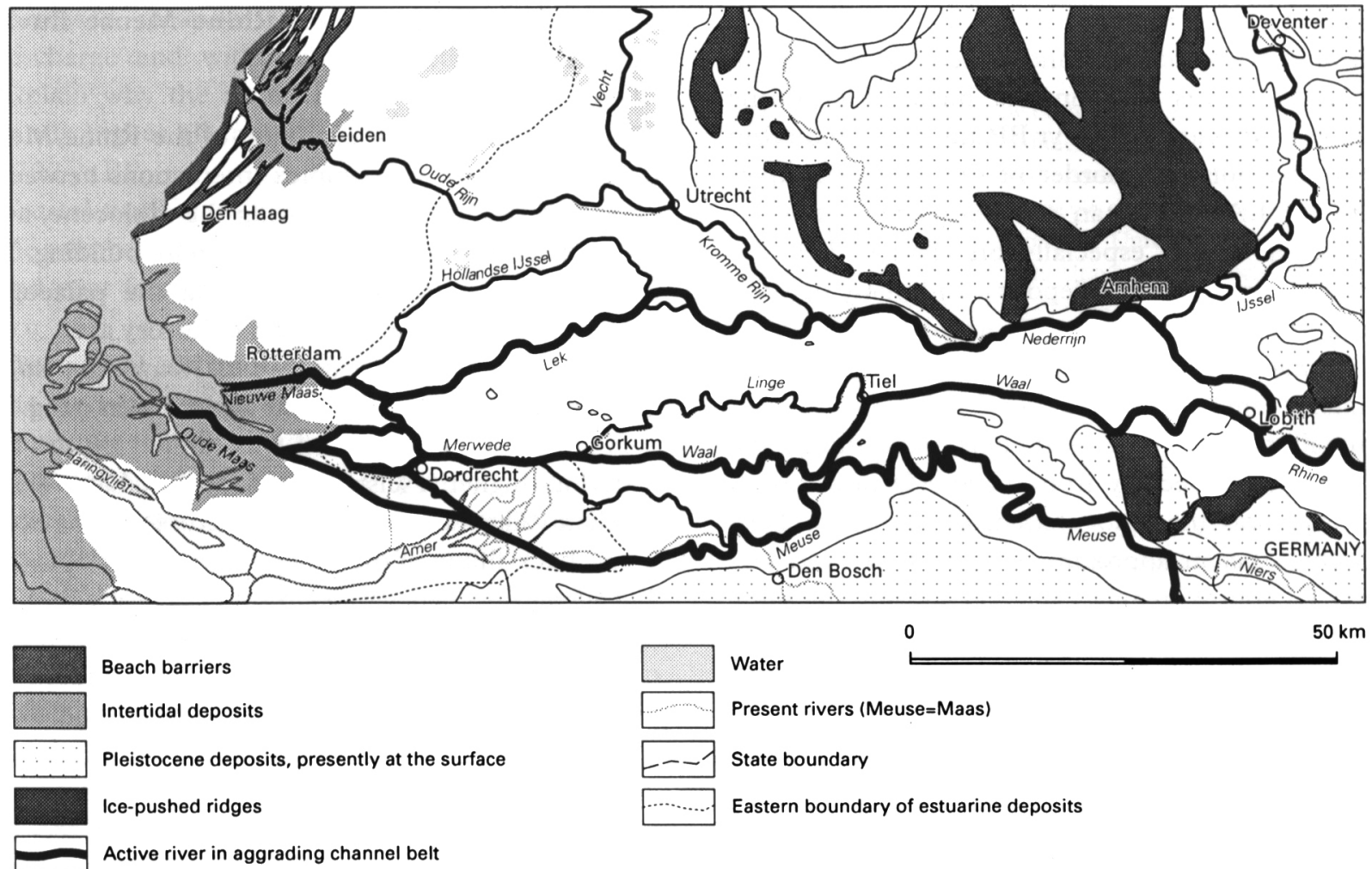

Fig. 11. Palaeogeographic maps for (a) $3200 \mathrm{yr}$ BP and (b) $1250 \mathrm{yr}$ BP. At these times only two large tidal inlets were present, and river channels had to rejoin before the tidal inlets were reached. (a) The Oude Rijn channel belt was the main distributary of the Rhine. The Linschoten river system rejoined the Oude Rijn near Woerden, and the Oude Rijn continued as a single channel belt, which debouched into the North Sea near Leiden. Other (smaller) channels of the Rhine and the Meuse debouched into a tidal inlet near Rotterdam. (b) The present rivers Lek, Waal, Meuse and IJssel had formed. Most branches of these rivers rejoined in the Rotterdam area before debouching into the North Sea. The main Rhine channels had shifted to the SW. Source coastal situation: CD-ROM 'De geologie van Zuid-Holland' from TNO-NITG (1998).

tially have been caused by increased precipitation. After 2000 yr BP, human influence most likely played a major role in determining discharge peaks. Especially deforestation in the upstream areas may have led to higher peak discharges of the order of magnitude of
$10 \%$ (Kwadijk 1993), and higher sediment loads of the rivers (Asselman 1997). This increase, however, seems insufficient to explain both the large increase of the meander wavelength, and the increase in the number of channels. Another significant factor may 
have been a decrease of river gradients as a result of sealevel rise. The resulting decrease of stream power may have caused within-channel sedimentation (Jones and Schumm 1999), leading to wider and shallower channels, bank erosion and enhanced lateral migration, and an increase in the number of avulsions.

We did not observe any systematic changes in channel widths, but the number of avulsions was indeed significantly higher from $3000-1700$ yr BP (Fig. 10). Clastic sedimentation increased after $2000 \mathrm{yr} B P$ all over the delta, and peat formation came to an end (Stouthamer and Berendsen 2000).

\section{Human influence}

Humans have been present in the Rhine-Meuse delta for the past 200,000 years, but human influence on the landscape is generally believed to have been insignificant until the Neolithic (6400-3650 yr BP), when forests were cleared and agriculture started on the natural levees and on the higher Pleistocene sands. Approximately $2000 \mathrm{yr}$ BP, the river Oude Rijn became the northern border of the Roman Empire (50 BC-400 AD). Roman occupation left many archaeological traces, especially on channel belt deposits and crevasse-splay deposits, and many new villages were established (Van Es and Hessing 1994). The Romans locally influenced the courses of rivers by digging canals.

Human influence increased enormously during the Middle Ages, especially from $1100 \mathrm{AD}$ onwards: A major step was the embankment of the main channels, which began approximately $1100 \mathrm{AD}$ and was completed approximately $1300 \mathrm{AD}$. During the same time period, the Kromme Rijn-Oude Rijn (1.122 $\mathrm{AD})$, the Hollandse IJssel (1285 AD) and the Linge (1305 AD) were dammed (Berendsen 1982), and their waters diverted. The damming of these distributaries reduced the number of Rhine branches to the present three. The Oude Rijn had silted up to a large extent since about $1050 \mathrm{AD}$, and the damming and diversion of the Kromme Rijn-Oude Rijn (Fig. 1) to the Lek reduced its water and sediment discharge to virtually zero.

Another important development was the occurrence of storm surges resulting in ingressions. The most important of these was the St. Elizabeth's flood of $1421 \mathrm{AD}$. As a result of the St. Elizabeth's flood, most of the older fluvial channels in the area SE of Dordrecht were eroded. The river Waal gradually enlarged, and the Lower Rhine-Lek silted up. To increase the discharge of the Lower Rhine-Lek and to improve shipping conditions on this river, the Panner- dens Canal (Fig. 1) was dug in $1707 \mathrm{AD}$. This significantly altered the discharge distribution over the Rhine distributaries. From then on, the discharge distribution has remained the same. Approximately 1860 $\mathrm{AD}$ the river Waal was connected to the Haringvliet estuary (Fig. 1) by the Nieuwe Merwede (actually this was an enlargement of an already existing tidal creek). The Brielsche Maas silted up (Terwindt 1992), and the Haringvliet became the main outlet for the Rhine system. In $1904 \mathrm{AD}$, a new outlet was also dug for the river Meuse (Berendsen 1986) to the Haringvliet estuary, the Bergsche Maas (Fig. 1). A new, wider and deeper outlet for the river Lek was created in $1872 \mathrm{AD}$ to benefit the port of Rotterdam by enlarging the Nieuwe Maas and digging the Rotterdam Waterway ('Nieuwe Waterweg'). In 1971 AD, the Haringvliet was closed off, forcing the main flow of Waal and Lek through the Nieuwe Maas.

\section{Summary of controls on Rhine-Meuse fluvial- deltaic history}

The palaeogeographic evolution of the Rhine-Meuse delta is governed by complex interactions between a large number of factors. During the Holocene, avulsion was an important process in delta building. The most important factors influencing the palaeogeographic evolution and the avulsion history are:

1. The location and shape of the Late Weichselian palaeovalley. In the area east of Amerongen (Fig. 1), Holocene river migration was limited by the bordering higher Pleistocene deposits. Late Weichselian valley margins were only crossed after extensive back-filling of the valley.

2. Sealevel rise. Sealevel rise resulted in back-filling of the palaeovalley. Approximately $4500 \mathrm{yr} \mathrm{BP}$, the coastal barriers became closed, and the direct influence of sealevel rise on the rivers diminished. However, sealevel rise continued at a slower rate, resulting in decreasing river gradients. Avulsion sites shifted upstream until $3700 \mathrm{yr} \mathrm{BP}$, when the Late Weichselian valley in the Netherlands was completely filled with Holocene sediments.

3. River channel pattern. Sealevel rise influenced stream power, resulting in a 'straight anastomosing' channel pattern that existed in the central-western part of the delta between approximately $7000 \mathrm{yr}$ BP and $2500 \mathrm{yr}$ BP. Although crevasse formation in this area was extensive, avulsion frequency was not higher than elsewhere.

4. Neotectonics. Differential tectonic movements of the Peel Horst and Roer Valley Graben seem to have influenced river behaviour, especially during the țime period 4500-2800 yr BP. Two important avul- 
sion nodes (Wijk bij Duurstede and Tiel) are located in the Peel Boundary Fault zone, and two avulsion nodes (Ochten and Nederasselt, see Fig. 1) are located in the Tegelen Fault zone.

5. Increased discharge, sediment load and/or within-channel sedimentation. After $2800 \mathrm{yr}$ BP and especially after $2000 \mathrm{yr}$ BP, meanders of Rhine distributaries and the river Meuse show remarkable increases in wavelengths. Moreover, the number of channels increased. This may be attributed to either increased bankfull discharge and sediment load, or increased within-channel sedimentation, or both. Higher discharges may have been caused by higher precipitation (after about $2800 \mathrm{yr} \mathrm{BP}$ ) and human influence (after $2000 \mathrm{yr} \mathrm{BP}$ ). Alternatively, continuing sealevel rise may have reduced stream power, leading to increased within-channel sedimentation and channel widening (although this has not been directly observed in the Rhine-Meuse delta), resulting in increased meander wavelengths. Both increased discharge and within-channel sedimentation can explain why the number of avulsions was significantly higher all over the delta between 3000 and 1700 yr BP.

6. Coastal evolution. When the coastal barriers closed, the number of tidal inlets was reduced to only two, and peat formation became extensive in the western part of the back-barrier area, especially between 4000 and $3000 \mathrm{yr}$ BP. This more or less fixed the river pattern at that time. This was especially important for the Oude Rijn channel belt, which became completely encased in peat, resisting lateral erosion. This led to a continuous reworking of the channel belt.

7. Composition of substrate and river banks. Meandering river channels tended to adhere to the sandy northern and southern margins of the Late Weichselian palaeovalley because river banks here consisted of sand, which is more readily eroded than the clayey and peaty deposits in the central part of the delta. Large meanders are found in areas where river banks consisted of sand, e.g., where coversands occur at shallow depth or where Younger Dryas eolian dunes and older channel deposits are present. Crevasse channels are especially found at places where sandy channels intersect or cross eolian dunes. Such crevasse channels may initiate avulsions, if a sufficient gradient advantage exists.

8. Marine ingressions. The $1421 \mathrm{AD}$ St. Elizabeth's flood caused large-scale erosion in the southwestern part of the fluvial deltaic plain and probably was instrumental in directing the main flows to the southwest. This process was amplified by human interference. Eventually this resulted in the demise of the Oude Rijn and the main discharge was diverted to the Meuse estuary by way of the rivers Lek and Waal.

9. Human influence. Since about $1100 \mathrm{AD}$, human influence dominated the palaeogeographic evolution of the Rhine-Meuse delta. Embankments fixed the rivers, and natural avulsions no longer occurred.

\section{Acknowledgements}

We thank Mark van Ree for his assistence in ${ }^{14} \mathrm{C}$ sampling. Wilco van Zijverden and Daan Hallewas (State Service for Archaeological Investigations = Rijksdienst voor Oudheidkundig Bodemonderzoek) were helpful in making the ARCHIS database available to us. Klaas van der Borg, Arie de Jong (Robert J. Van de Graaff Laboratory, Utrecht University) and Hans van der Plicht (Centre for Isotope Research (CIO), Groningen University) carried out the ${ }^{14} \mathrm{C}$ datings.

\section{References}

Allen, J.R.L., 1965. A review of the origin and characteristics of recent alluvial sediments. Sedimentology 5: 89-191.

Asselman, N.E.M., 1997. Suspended sediment in the River Rhine. The impact of climate change on erosion, transport and deposition. Ph.D. Thesis Utrecht University, KNAG/Faculteit Ruimtelijke Wetenschappen Universiteit Utrecht: Netherlands Geographical Studies 234: 257 pp.

Beets, D.J., Van der Valk, L. and Stive, M.F.J., 1992. Holocene evolution of the coast of Holland. Marine Geology 103: 423-443.

Berendsen, H.J.A., 1982. De genese van het landschap in het zuiden van de provincie Utrecht, een fysisch-geografische studie. Ph.D. Thesis (with summary in English), Utrechtse Geografische Studies 10:256 pp.

Berendsen, H.J.A. (Ed.), 1986. Het landschap van de Bommelerwaard. With summary in English. Nederlandse Geografische Studies 10: $184 \mathrm{pp}$.

Berendsen, H.J.A., 1990. River courses in the central Netherlands during the Roman Period. Berichten van de Rijksdienst voor het Oudheidkundig Bodemonderzoek 40: 243-249.

Berendsen, H.J.A., 1998. Bird's-eye view of the Rhine-Meuse delta. The World Deltas Symposium, New Orleans, Journal of Coastal Research 14: 740-752.

Berendsen, H.J.A., Hoek, W.Z. and Schorn, E.A., 1995. Late Weichselian and Holocene River Channel Changes of the Rivers Rhine and Meuse in the Central Netherlands (Land van Maas en Waal). In: Frenzel, B., (ed.): European river activity and climate change during the Lateglacial and early Holocene. ESF Project European Palaeoclimate and Man 9. Paläoklimaforschung / Paleoclimate Research 14: 151-171.

Berendsen, H.J.A. and Stouthamer, E., 2000. Late Weichselian and Holocene palaeogeography of the Rhine-Meuse delta, The Netherlands. Palaeogeography, Palaeoclimatology, Palaeoecology 161:311-335.

Berendsen, H.J.A. and Stouthamer, E., 2001. Palaeogeographical development of the Rhine-Meuse delta, The Netherlands. Van Gorkum (Assen): $250 \mathrm{pp}$.

Bohncke, S., Vandenberghe, J. and Huijzer, A.S., 1993. Periglacial paleoenvironment during the Late Glacial in the Maas valley, The Netherlands. Geologie en Mijnbouw 72: 193-210. 
Friedrich, M., Kromer, B., Spurk, M., Hofmann, J. and Kaiser, K.F., 1999. Paleo-environment and radiocarbon calibration as derived from Lateglacial/Early Holocene tree-ring chronologies. Quaternary International 61: 27-39.

Hoek, W.Z., 1997. Palaeogeography of Lateglacial Vegetations: Aspects of Lateglacial and Early Holocene vegetation, the abiotic landscape and climate of the Netherlands, and Atlas to Palaeogeography of Lateglacial Vegetations: Maps of the Lateglacial and Early Holocene landscape and vegetation of the Netherlands, with an extensive review of Palynological data. Ph. D. Thesis, Free University, Amsterdam. Also published as: Netherlands Geographical Studies 230 and 231, KNAG, Utrecht.

Huisink, M., 1997. Lateglacial sedimentological and morphological changes in a lowland river in response to climate change: the Maas, southern Netherlands. Journal of Quaternary Science 12: 209-223.

Jones, L.S. and Schumm, S.A., 1999. Causes of avulsion: an overview, In: Smith, N.D., and Rogers, J. (eds.): Fluvial Sedimentology VI, Spec. Publs. Int. Ass. Sediment. 28: 171-178.

Kasse, C., Vandenberghe, J. and Bohncke, S.J.P., 1995. Climatic change and fluvial dynamics of the Maas during the Late Weichselian and Early Holocene. Paläoklimaforschung / Palaeoclimate Research Vol 14: 123-150.

Kwadijk, J., 1993. The impact of climate change on the discharge of the River Rhine. Ph.D. Thesis Utrecht University, KNAG/ Faculteit Ruimtelijke Wetenschappen Universiteit Utrecht, Netherlands Geographical Studies 171:208 pp.

Makaske, B., 1998. Anastoming rivers - Forms, processes and sediments. Ph. D. Thesis. Utrecht: KNAG/Faculteit Ruimtelijke Wetenschappen Universiteit Utrecht, Netherlands Geographical Studies 249:287 pp.

Makaske, B. and Nap, R.L., 1995. A transition from a braided to a meandering channel facies, showing inclined heterolithic stratification (Late Weichselian, central Netherlands). Geologie en Mijnbouw 74: 13-20.

Miedema, R., 1987. Soil formation, microstructure and physical behaviour of Late Weichselian and Holocene Rhine deposits in the Netherlands. Ph. D. Thesis, Wageningen: 339 pp.

Nederlands Instituut voor Toegepaste Geowetenschappen, 1998. De geologie van Zuid-Holland. Utrecht: NITG-TNO, CDROM.

Pons, L.J., 1957. De geologie, de bodemvorming en de waterstaatkundige ontwikkeling van het Land van Maas en Waal en een gedeelte van het Rijk van Nijmegen. 's-Gravenhage: Verslagen van Landbouwkundige Onderzoekingen 63.11, Dissertatie Wageningen. Bodemkundige Studies 3: $156 \mathrm{pp}$.

Pons, L.J. and Schelling, J., 1951. De laatglaciale afzettingen van de Rijn en de Maas. Geologie en Mijnbouw 13: 293-297.

Smith, N.D., Cross, T.A., Dufficy, J.P. and Clough, S.R., 1989. Anatomy of an avulsion. Sedimentology 36: 1-23.

Steenbeek, R., 1990. On the balance between wet and dry. Vegetation horizon development and prehistoric occupation; a palaeoecological - micromorphological study in the Dutch river area. Ph. D. Thesis, Free University, Amsterdam: 267 pp.

Stouthamer, E. and Berendsen, H.J.A., 2000a. Factors controlling the Holocene avulsion history of the Rhine-Meuse delta (The Netherlands). Journal of Sedimentary Research 70: 1051-1064.

Terwindt, J.H.J., 1992. Het gedrag van de kust. Dies-rede, Utrecht University, $10 \mathrm{p}$.

Teunissen, D. and Teunissen-van Oorschot, H., 1974. Eine interstadiale Torfschicht bei Nijmegen (Niederlande) und deren Bedeutung für die Erklärung der dortigen Landschaft morphologie. Geologie en Mijnbouw 53: 393-400.
Törnqvist, T.E., 1993a. Fluvial sedimentary geology and chronology of the Holocene Rhine-Meuse delta, The Netherlands. Ph.D. Thesis Utrecht University, KNAG/Faculteit Ruimtelijke Wetenschappen Universiteit Utrecht, Netherlands Geographical Studies $166: 176 \mathrm{pp}$.

Törnqvist, T.E., 1993b. Holocene alternation of meandering and anastomosing fluvial systems in the Rhine-Meuse delta (central Netherlands) controlled by sea-level rise and subsoil erodibility. Journal of Sedimentary Petrology 63: 683-693.

Törnqvist, T.E., 1998. Longitudinal profile evolution of the RhineMeuse system during the last deglaciation: interplay of climate change and glacio-eustasy? Terra Nova 10: 11-15.

Törnqvist, T.E. and Van Dijk, G.J., 1993. Optimizing sampling strategy for radiocarbon dating of Holocene fluvial systems in a vertically aggrading setting. Boreas 22: 129-145.

Törnqvist, T.E., Weerts, H.J.T. and Berendsen, H.J.A., 1994. Definition of two new members in the upper Kreftenheye and Twente Formations (Quaternary, The Netherlands): a final solution to persistent confusion? Geologie en Mijnbouw 72: 251264.

Törnqvist, T.E., Van Ree, M., Van 't Veer, R. and Van Geel, B., 1998. Improving Methodology for High-resolution Reconstruction of Sea-level Rise and Neotectonics by Paleoecological Analysis and AMS ${ }^{14} \mathrm{C}$ Dating of Basal Peats (Rhine-Meuse Delta, The Netherlands). Quaternary Research 49: 72-85.

Van de Meene, E.A., 1979. Het ontstaan van de Geldersche IJssel. Koninklijk Nederlands Aardrijkskundig Genootschap, Geografisch Tijdschrift, Nieuwe Reeks 13: 202-210.

Van de Meene, E.A. and Zagwijn, W.H., 1978. Die Rheinlaufe im deutsch-niederländischen Grenzgebiet seit der Saale-Kaltzeit. Überblick neuer geologischer und pollenanalytischer Untersuchungen. Fortschr. Geol. Rheinld. u. West 28: 345-359.

Van der Valk, L., 1992. Mid- and Late Holocene Coastal Evolution in the Beach-Barrier Area of the Western Netherlands. Ph. D. Thesis Vrije Universiteit Amsterdam: 235 pp.

Van Dijk, G.J., Berendsen, H.J.A. and Roeleveld, W., 1991. Holocene water level development in The Netherlands' river area; implications for sea-level reconstruction. Geologie en Mijnbouw 70:311-326.

Van Es, W.A. and Hessing, W.A.M., (Eds.) 1994., Romeinen, Friezen en Franken. Utrecht: Matrijs, Amersfoort: ROB.

Van Geel, B., Buurman, J. and Waterbolk, H.T., 1996. Archaeologi$\mathrm{cal}$ and palaeocological indications of an abrupt climate change in the Netherlands, and evidence for climatological teleconnections around $2650 \mathrm{BP}$. Journal of Quaternary Science 11: 451460 .

Vandenberghe, J., 1987. Changing fluvial processes in a small lowland valley at the end of the Weichselian Pleniglacial and during the Late Glacial. In: Gardiner, V. (Ed.): Proceedings of the First International Conference on Geomorphology, Part 1, Manchester 1986: 731-747.

Verbraeck, A., 1984. Toelichtingen bij de geologische kaart van Nederland, schaal 1:50.000, bladen Tiel West $(39 \mathrm{~W})$ en Tiel Oost (39O). Rijks Geologische Dienst, Haarlem: 335 pp.

Verbraeck, A., 1990. De Rijn aan het einde van de laatste ijstijd: De vorming van de jongere afzettingen van de Formatie van Kreftenheye. Geografisch Tijdschrift Nieuwe Reeks XXIV: 328-340.

Weerts, H.J.T. and Berendsen, H.J.A., 1995. Late Weichselian and Holocene fluvial palaeogeography of the southern Rhine-Meuse delta (The Netherlands). Geologie en Mijnbouw 74: 199-212.

Zagwijn, W.H., 1986. Nederland in het Holoceen. Staatsdrukkerij ('s-Gravenhage): $46 \mathrm{pp}$. 